\title{
Spectrophotometric Methods for Simultaneous Determination of Rivaroxaban and Clopidogrel in Their Binary Mixture
}

Sharaf EI-Din M, Ibrahim F, Shalan SH* and Abd El-Aziz H

Department of Analytical Chemistry, Faculty of Pharmacy, University of Mansoura, Egypt

\begin{abstract}
Three rapid, accurate and very simple derivative spectrophotometric methods for RIV and CLP assay in their binary mixture and tablet dosage forms were developed. Method (I) is first derivative spectrophotometric method, derivative amplitudes were measured at the zero crossing wavelength of 289 and $249.5 \mathrm{~nm}$ for estimation of RIV and CLP, respectively. The linearity is over the range $2.0-20.0 \mu \mathrm{g} / \mathrm{ml}$ for RIV and $5.0-60.0 \mu \mathrm{g} / \mathrm{ml}$ for CLP with LOD of 0.211 and $0.361 \mu \mathrm{g} \mathrm{mL}^{-1}$ and LOQ of 0.641 and $1.095 \mu \mathrm{g} \mathrm{mL}-1$ for RIV and CLP, respectively. Method (II) is ratio derivative spectrophotometric method. The ratio spectra of each drug were derived by dividing its spectra on a constant concentration of the other drug as a divisor. Derivative amplitudes were measured at $256 \mathrm{~nm}$ for RIV and at $214.5 \mathrm{~nm}$ for CLP over the same linearity range as the first method with LOD of 0.137 and $0.485 \mu \mathrm{gL} \mathrm{m}^{-1}$ and LOQ of 0.417 and $1.471 \mathrm{\mu g} \mathrm{mL}^{-1}$ for RIV and CLP, respectively. Method (III) is absorbance ratio method, absorbance of both drugs were recorded at two wavelengths $\lambda_{1}$ (232) iso-absorptive point and $\lambda_{2}(249) \lambda_{\max }$ of RIV. The final concentrations were obtained by applying the $Q$ equations. The method was linear over the same concentration range as the first method with LOD of 0.272 and $0.485 \mu \mathrm{g} \mathrm{mL}^{-1}$ and LOQ of 0.826 and $1.471 \mu \mathrm{g} \mathrm{mL}^{-1}$ for RIV and CLP, respectively. The proposed methods were validated as per ICH guidelines. The proposed methods were successfully applied to both drugs analysis in their laboratory prepared co formulated tablet. Statistical comparison of the obtained results with those of the reference method show good agreement and confirm that there were no significant difference in the accuracy and precision between the proposed and reference one respectively.
\end{abstract}

Keywords: Rivaroxaban (RIV); Clopidogrel (CLP); Spectrophotometric methods; Binary mixture

\section{Introduction}

Rivaroxaban (Figure 1a); (S)-5-chloro-N-\{[2-oxo-3-[4-(3-oxomorpholin4-yl)phenyl] oxazolidin-5-yl]methyl\} thiophene-2-carboxamide [1], is considered one of the available orally active anticoagulants, its mechanism of action was direct factor Xa inhibitor. (FDA) approved rivaroxaban to avoid occurrence of deep vein thrombosis which may cause pulmonary embolism in adults with hip and knee replacement surgery [2]. Clopidogrel (Figure 1b); ((+)-(S)-methyl2-(2-chlorophenyl)2 -(6,7-dihydrothieno[3,2-c]pyridin-5(4H)yl)acetate [1], is an oral anticoagulant agent belongs to thienopyridine - class acts by inhibiting adenosine diphosphate-mediated platelet aggregation [2]. Both drugs are used to prevent blood clots in coronary artery disease, peripheral and cerebro vascular disease and to avoid myocardial infarction [2]. RIV is not official in any pharmacopoeia. Few spectrophotometric methods have been reported for determinations of RIV [3,4]. Two HPTLC methods were explored for the evaluation of RIV in tablet dosage form [5,6]. Many HPLC methods were reported in literature for RIV assay in pure form, pharmaceutical formulations and biological matrices [7-13]. For CLP, it is official in the United State Pharmacopeia (USP) [14] and British Pharmacopeia (BP) [15]. Literature survey reveals<smiles>O=C(NC[C@H]1CN(c2ccc(N3CCOCC3=O)cc2)C(=O)O1)c1ccc(Cl)s1</smiles>

(a) Rivaroxaban

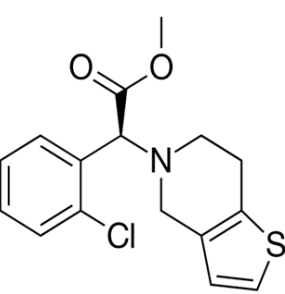

(b) Clopidogrel
Figure 1: The structural formulae of the studied drugs. many reported spectrophotometric methods for CLP determination [16-19]. Many HPLC methods were published for its evaluation [20-23]. The present work provides three optimized and validated spectrophotometric methods for simultaneous determination of both drugs showing high simplicity. Validation for the proposed methods was done as per International Conference on Harmonization (ICH) guidelines.

\section{Experimental Study}

\section{Equipments}

The Spectrophotometric measurements were carried out using Shimadzu UV-Visible double-beam 1601 recording Spectrophotometer (Kyoto, Japan) (P/N 206-67001); with matched $1 \mathrm{~cm}$ path-length quartz cuvettes.

The first derivative spectra of both drugs were scanned in the wavelength range $(200-320) \mathrm{nm}$ with $\Delta \lambda=8 \mathrm{~nm}$ and applying scaling factor $=10$.

The ratio derivative spectra for RIV were recorded in the wavelength range (235-284) $\mathrm{nm}$ applying $\Delta \lambda=2 \mathrm{~nm}$ and scaling factor $=1$ to produce a smooth ratio spectra and $\Delta \lambda=4 \mathrm{~nm}$ for the first derivative of ratio spectra appling scaling factor $=10$. Meanwhile,

*Corresponding author: Shereen Shalan, Department of Analytical Chemistry, Faculty of Pharmacy, University of Mansoura, Egypt, Tel: +201093335779; Fax +20502247496; E-mail: shereenshalan@yahoo.com

Received November 12, 2017; Accepted January 27, 2018; Published January 31, 2018

Citation: Sharaf EDM, Ibrahim F, Shalan SH, Abd El-Aziz H (2018) Spectrophotometric Methods for Simultaneous Determination of Rivaroxaban and Clopidogrel in Their Binary Mixture. Pharm Anal Acta 9: 575. doi: 10.4172/2153-2435.1000575

Copyright: @ 2018 Sharaf EDM, et al. This is an open-access article distributed under the terms of the Creative Commons Attribution License, which permits unrestricted use, distribution, and reproduction in any medium, provided the original author and source are credited. 
the ratio derivative spectra for CLP were recorded in the wavelength range (200-280) $\mathrm{nm}$ with $\Delta \lambda=2 \mathrm{~nm}$ and scaling factor $=1$ and $\Delta \lambda=$ $4 \mathrm{~nm}$ for the first derivative of the produced ratio spectra with scaling factor $=10$.

Ultrasonic bath (Model: SS 101 H 230, USA) used for sonication of all prepared solutions.

\section{Materials and reagents}

-Rivaroxaban and Clopidogrel were purchased from Memphis Co. for pharm. \& Eva Pharma Company, Cairo, Egypt, respectively.

-Laboratory prepared tablet consists of $15 \mathrm{mg}$ RIV, $75 \mathrm{mg}$ CLP, 15 mg maize starch, $15 \mathrm{mg}$ lactose, $7 \mathrm{mg}$ magnesium stearate and $20 \mathrm{mg}$ talc powder.

-Methanol was purchased from Sigma- Aldrich (Germany) as HPLC grade.

\section{Standard solutions}

Standard stock solutions of $10.0 \mathrm{mg} / 100 \mathrm{ml}$ for each of Rivaroxaban and Clopidogrel were prepared separately in methanol. Using methanol for dilution of the stock solutions, working solutions were appropriately prepared. An additional stock solution was prepared using $50 \mathrm{mg} / 100 \mathrm{ml}$ of Clopidogrel to be used in synthetic mixture preparation. The drugs kept stable for not less than 3 weeks without alteration when stored in the refrigerator.

\section{Calibration graphs establishment}

$\mathrm{D}^{1}$ method: A series of $10 \mathrm{ml}$ volumetric flasks was used. Transfer accurately measured volumes of the drug working standard solutions to reach final concentration in the range of $2.0-20.0 \mu \mathrm{g} / \mathrm{ml}$ for RIV and $5.0-60.0 \mu \mathrm{g} / \mathrm{ml}$ for CLP. Dilute with methanol to the volume and mix well. RIV and CLP zero-order absorption spectra were recorded against blank methanol (Figure 2). The first derivatives of the zeroorder spectra were recorded. The derivative amplitudes were measured at the zero crossing wavelength of 289 and $249.5 \mathrm{~nm}$ for determination of RIV and CLP, respectively (Figures 3 and 4). A plot of derivative absorbance amplitudes was then drawn against the final concentrations. Also, we derived the corresponding regression equations from the obtained data.

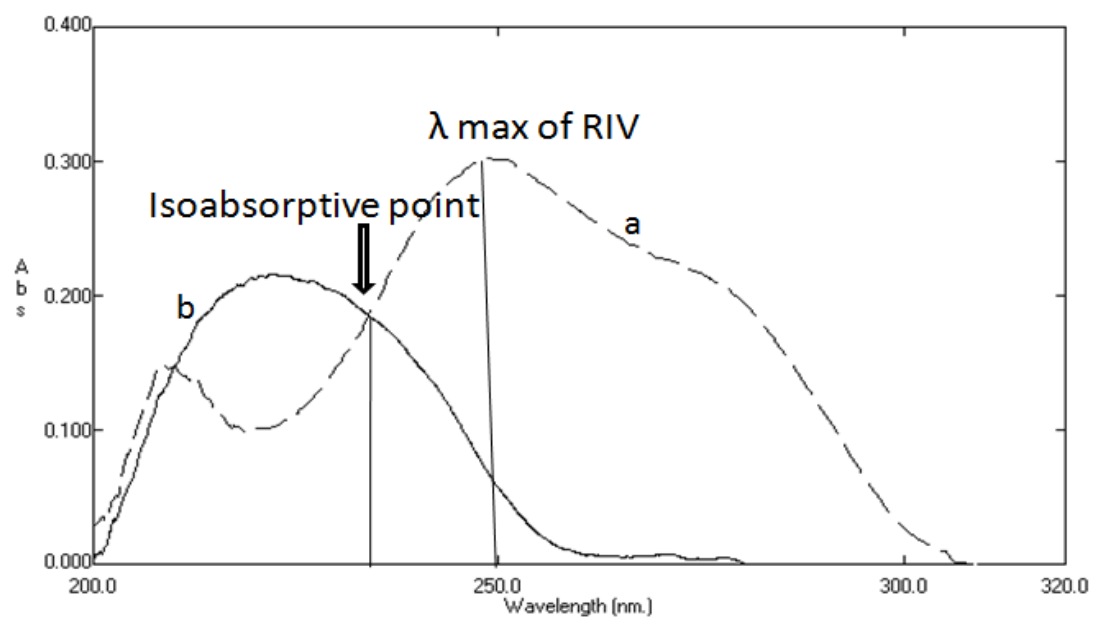

Figure 2: Zero order absorption spectra of RIV (a; $5.0 \mu \mathrm{g} / \mathrm{ml})$ and CLP (b; $10.0 \mu \mathrm{g} / \mathrm{ml})$ in methanol.

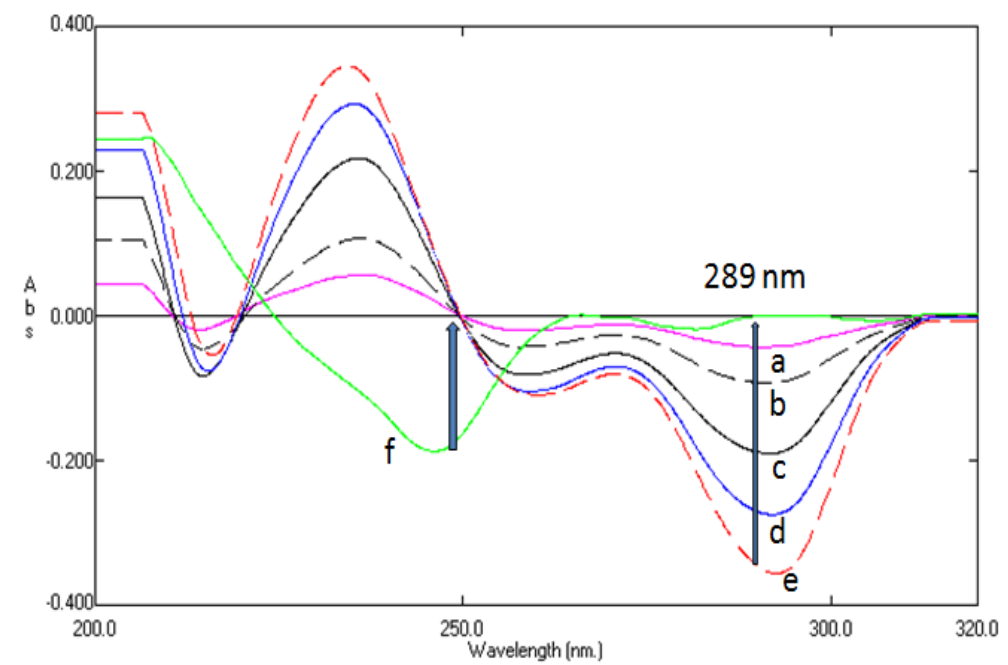

Figure 3: First order absorption spectra of methanolic solution of RIV (a: e) (2.0, 5.0, 10.0, 15.0, $20.0 \mu \mathrm{g} / \mathrm{mL})$ and CLP (f) $(20.0 \mu \mathrm{g} / \mathrm{mL})$. 
Ratio derivative spectrophotometry: In case of using ratio derivative spectrophotometry, the first derivative of the ratio spectra (all RIV spectra were divided by CLP spectrum $(20.0 \mu \mathrm{g} / \mathrm{mL}$ ) (Figures 5 and 6) and all CLP spectra were divided by RIV spectrum of $5.0 \mu \mathrm{g} / \mathrm{mL}$ ) were derived (Figures 7 and 8). After measuring the amplitudes at 256 $\mathrm{nm}$ for RIV and at $214.5 \mathrm{~nm}$ for CLP, the derivative amplitudes were plotted against the final concentrations to obtain the calibration curves.

Absorbance ratio method: Determination of drugs by absorbance ratio method was also derived, absorbance of both drugs were recorded at two wavelengths $\lambda_{1}$ (232) iso-absorptive point and $\lambda_{2}(249) \lambda_{\max }$ of RIV (Figure 2). The final concentrations were obtained by applying the $\mathrm{Q}$ equations.

\section{Application of the proposed methods (I, II, III) to RIV/CLP binary mixtures assay}

Accurate aliquots of RIV and CLP standard solutions in their pharmaceutical ratio (1:5) were transferred into a series of $10 \mathrm{~mL}$ volumetric flasks. The solutions were diluted with methanol to the volume and then mixed well. The steps stated under "Calibration Graphs Establishment" (a, b, c) were then followed. Graphs of derivative amplitudes against the final concentrations were plotted to obtain the linearity range.

\section{proposed method application for determination of riv and clp in their laboratory prepared co-formulated tablets}

Ten laboratory prepared tablets were mixed well, then amount equivalent to $15 \mathrm{mg}$ RIV and $75 \mathrm{mg}$ CLP were accurately weighed and transferred into $100 \mathrm{~mL}$ volumetric flask and about $80 \mathrm{~mL}$ of methanol were added. Sonication of the flask contents for 30 min was applied, and then the flask was completed to the volume with the same solvent and filtered. Aliquot volumes of the filtrate of suitable concentrations in the working concentration ranges for both studied drugs were assayed as illustrated under "Calibration Graphs Establishment". Tablet contents were calculated using calibration graph or corresponding regression equations.

\section{Results and Discussion}

RIV UV spectrum showed maxima at 210 and $248 \mathrm{~nm}$ and for

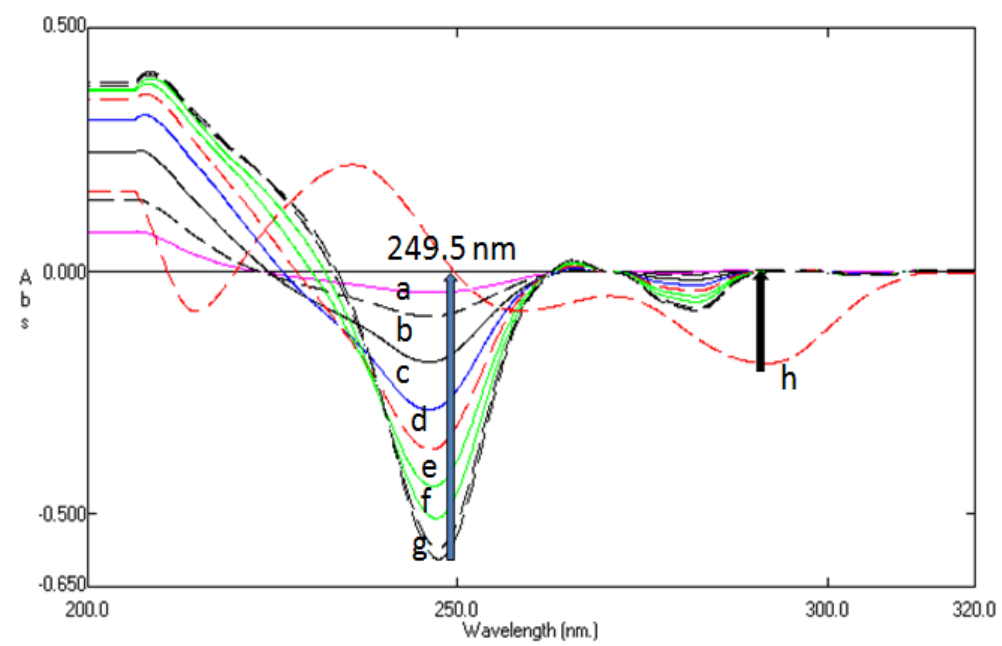

Figure 4: First order absorption spectra of methanolic solution of CLP (a: g) (5.0, 10.0, 20.0, 30.0, 40.0, 50.0, $60.0 \mu \mathrm{g} / \mathrm{mL})$ and RIV (h) $(10.0 \mu \mathrm{g} / \mathrm{mL})$.

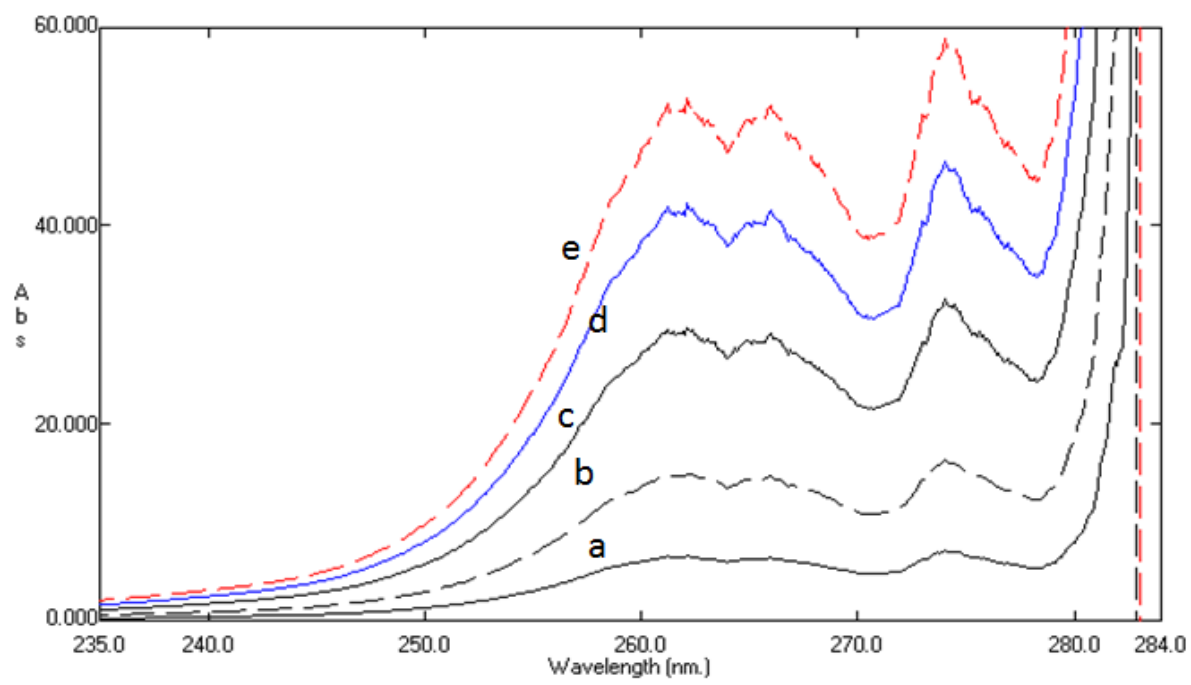

Figure 5: Ratio spectra of RIV (a: e) divided by CLP $(20.0 \mu \mathrm{g} / \mathrm{mL})$ as a divisor in methanol. 


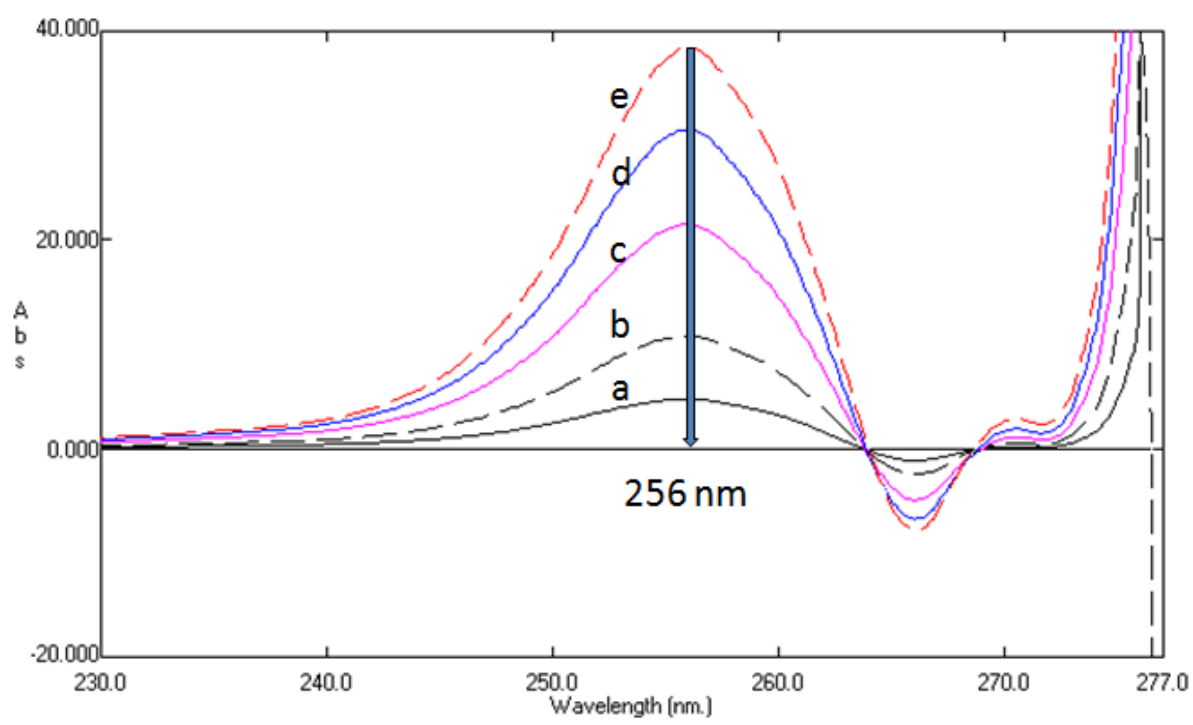

Figure 6: Ratio derivative spectra of RIV (a: e) divided by CLP $(20.0 \mu \mathrm{g} / \mathrm{mL})$ as a divisor in methanol.

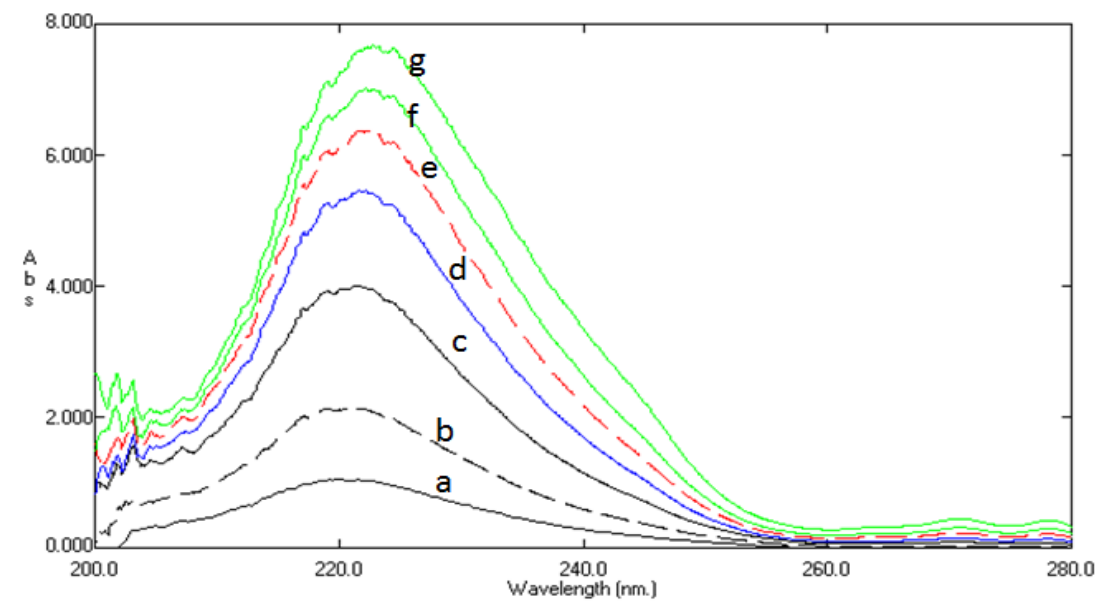

Figure 7: Ratio spectra of CLP (a: g) divided by RIV $(5.0 \mu \mathrm{g} / \mathrm{mL})$ as a divisor in methanol.

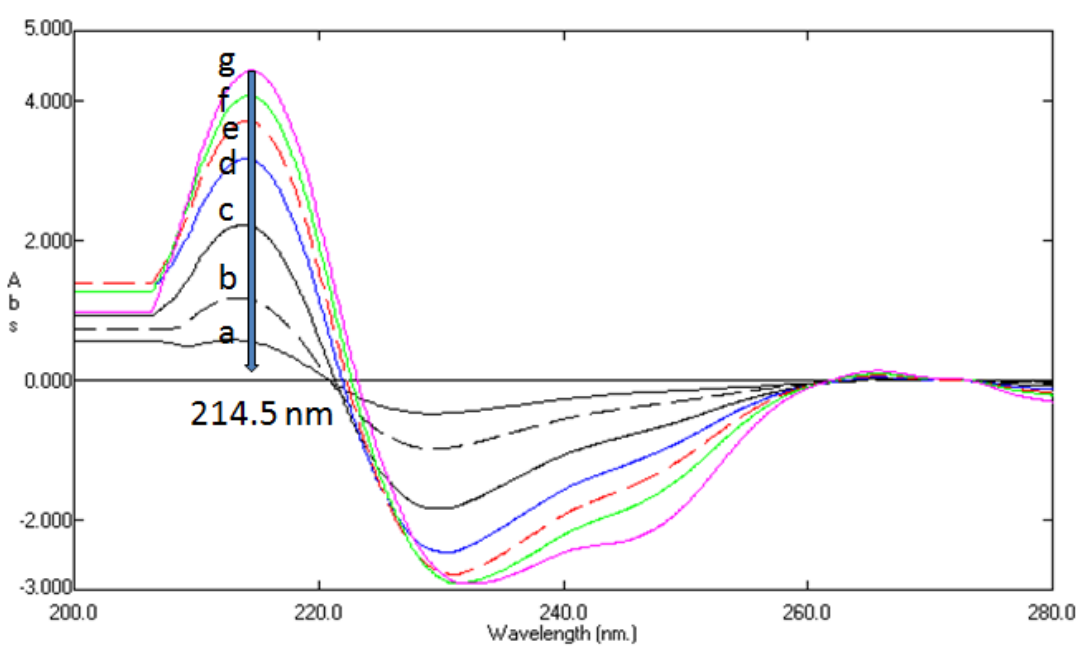

Figure 8: Ratio derivative spectra of CLP (a: g) divided by RIV $(5.0 \mu \mathrm{g} / \mathrm{mL})$ as a divisor in methanol. 
Citation: Sharaf EDM, Ibrahim F, Shalan SH, Abd El-Aziz H (2018) Spectrophotometric Methods for Simultaneous Determination of Rivaroxaban and Clopidogrel in Their Binary Mixture. Pharm Anal Acta 9: 575. doi: 10.4172/2153-2435.1000575

Page 5 of 9

CLP $222 \mathrm{~nm}$ (Figure 2). Due to this overlap, RIV can be evaluated in presence of CLP in the zero order spectra but the readings were of low sensitivity at $275 \mathrm{~nm}$ and CLP cannot be estimated in presence of RIV. Thus, we developed three spectrophotometric methods (derivative and ratio derivative and ratio absorbance) for the quantification of both drugs in the presence of each other.

\section{First derivative spectrophotometric method}

The use of derivative spectrophotometric technique make enhancement for the UV absorption spectrum features; the first derivative spectra of both RIV and CLP (Figures 3 and 4) permitted more specific and highly selective determination of each drug at the zero-crossing point of the other. The first derivative amplitudes at 289 $\mathrm{nm}$ (zero-crossing of CLP) and at $249.5 \mathrm{~nm}$ (zero-crossing of RIV) were selected for assay of RIV and CLP in their binary mixtures, respectively.

\section{Ratio derivative spectrophotometry}

Figure 5 illustrates the ratio spectra of RIV standards in different concentrations (RIV spectra divided by $20.0 \mu \mathrm{g} / \mathrm{mL}$ of CLP spectrum) while Figure 6 shows their corresponding first derivative spectra. In this figure, the amplitude at $256 \mathrm{~nm}\left({ }^{1} \mathrm{DD}_{256}\right)$ corresponds to RIV present in the solution, so it can be used for its quantitative assay.

Likewise, Figure 7 and 8 shows the ratio spectra of different concentrations of CLP standards (spectra divided by the spectrum of $5.0 \mu \mathrm{g} / \mathrm{mL}$ RIV solution) as well as their corresponding first derivative spectra, on the basis of which, CLP can be estimated by measuring the amplitude at $214.5 \mathrm{~nm}\left({ }^{1} \mathrm{DD}_{214.5}\right)$.

The effect of $\Delta \lambda$ for obtaining the first derivative of the ratio spectra was tested to obtain the best wavelength interval; $\Delta \lambda=8 \mathrm{~nm}$ was considered as suitable for both drugs. CLP $(20.0 \mu \mathrm{g} / \mathrm{ml})$ and RIV $(5 \mu \mathrm{g}$ $/ \mathrm{ml}$ ) were selected as the most suitable divisor concentration in relation to signal-to-noise ratio and sensitivity for evaluation of RIV and CLP, respectively.

\section{Absorbance ratio method}

Figure 2 shows the iso-absorptive point at which both drugs have the same absorbance value and $\lambda$ max for RIV. Absorbance of each drug was measured twice; at the iso-absorptive point and at $\lambda$ max for RIV, then calibration for each drug alone was performed and specific absorptivities of both drugs were determined.

Relative concentration of the two drugs in the mixture was calculated by applying the following equations [24].

$$
\begin{aligned}
& C_{x}=\left[\left(Q_{M}-Q_{y}\right) /\left(Q_{x}-Q_{y}\right)\right] \times A_{1} / a_{x 1} \\
& C_{y}=\left[\left(Q_{M}-Q_{x}\right) /\left(Q_{y}-Q_{x}\right)\right] \times A_{1} / a_{y 1}
\end{aligned}
$$

Where $Q_{M}=A_{2}$ (absorbance of the sample at $248.5 \mathrm{~nm}$ )/ $A_{1}$ (absorbance of the sample at $233.7 \mathrm{~nm}$ ), $\mathrm{Q}_{\mathrm{x}}=\mathrm{a}_{\mathrm{x} 2}$ (absorptivity of RIV at $248.5 \mathrm{~nm}$ ) $/ \mathrm{a}_{\mathrm{x} 1}$ (absorptivity of RIV at $233.7 \mathrm{~nm}$ ) $\mathrm{Q}_{\mathrm{y}}=\mathrm{a}_{\mathrm{y} 2}$ (absorptivity of CLP at $248.5 \mathrm{~nm}$ ) / $\mathrm{a}_{\mathrm{y} 1}$ (absorptivity of CLP at $233.7 \mathrm{~nm}$ ).

$\mathrm{A}_{1}$ and $\mathrm{A}_{2}$ are the absorbance of the mixture at $233.7 \mathrm{~nm}$ and 248.5 $\mathrm{nm}$, respectively.

$\mathrm{a}_{\mathrm{x} 1}$ and $\mathrm{a}_{\mathrm{y} 1}$ are the absorptivities of RIV and CLP at $233.7 \mathrm{~nm}, \mathrm{a}_{\mathrm{x} 2}$ and $\mathrm{a}_{\mathrm{y} 2}$ are the absorptivities of RIV and CLP at $248.5 \mathrm{~nm}$.

\section{Proposed Methods Validation}

\section{Linearity and range}

A plot of the derivative amplitude against the drug concentration in $\mu \mathrm{g} / \mathrm{ml}$ showed a linear relationship over the range $2.0-20.0 \mu \mathrm{g} / \mathrm{mL}$ for RIV and 5.0-60.0 $\mu \mathrm{g} / \mathrm{mL}$ for CLP. The concentration ranges over which linearity was cited in Tables 1 and 2 .

The following equations were obtained from data regression analysis:

$$
\begin{aligned}
& \mathrm{DA}=0.010+0.017 \mathrm{C}(\mathrm{r}=0.9999) \text { for RIV at } 289 \mathrm{~nm} . \\
& \mathrm{DA}=0.005+0.008 \mathrm{C}(\mathrm{r}=0.9999) \text { for CLP at } 249.5 \mathrm{~nm} .
\end{aligned}
$$

The ratio first derivative method resulted in the following equations:

$\mathrm{DA}=0.010+0.017 \mathrm{C}(\mathrm{r}=0.9999)$ for RIV at $256 \mathrm{~nm}$.

$\mathrm{DA}=0.005+0.008 \mathrm{C}(\mathrm{r}=0.9999)$ for CLP at $214.5 \mathrm{~nm}$.

Illustration: DA refers to the derivative amplitude, $\mathrm{C}$ refers to drug concentration in $\mu \mathrm{g} / \mathrm{mL}$ and correlation coefficient is $\mathrm{r}$.

High (r) values and small values of intercepts prove that calibration curves were of high linearity.

Q equations for absorbance ratio method were represented as follow:

$$
\begin{aligned}
& C_{x}=\left[\left(Q_{M}-0.4228\right) /(1.5401-0.4228)\right] \times A_{1} / 0.0337 \\
& C_{y}=\left[\left(Q_{M}-1.5401\right) /(0.4228-1.5401)\right] \times \mathrm{A}_{1} / 0.0149
\end{aligned}
$$

The linearity of absorbance ratio method was performed for each drug twice (at iso-absorptive point and at $\lambda_{\text {max }}$ of RIV).

From data of statistical analysis $[24,25]$ it was found that the

\begin{tabular}{|c|c|c|}
\hline \multirow{2}{*}{ Parameter } & \multicolumn{2}{|c|}{ Results } \\
\cline { 2 - 3 } & RIV & CLP \\
\hline Linearity range $(\mu \mathrm{g} / \mathrm{mL})$ & $2.0-20.0$ & $5.0-60.0$ \\
\hline$(\mathrm{a})$ & 0.01 & 0.005 \\
\hline$(\mathrm{b})$ & 0.017 & 0.008 \\
\hline$(\mathrm{r})$ & 0.9999 & 0.9999 \\
\hline$(\mathrm{Sy} / \mathrm{x})$ & $1.3 \times 10^{-3}$ & $1.2 \times 10^{-3}$ \\
\hline$(\mathrm{Sa})$ & $1.1 \times 10^{-3}$ & $9.0 \times 10^{-4}$ \\
\hline$(\mathrm{Sb})$ & $1.0 \times 10^{-4}$ & 0 \\
\hline$\% \mathrm{RSD}$ & 0.69 & 0.73 \\
\hline$\% \mathrm{Error}$ & 0.31 & 0.27 \\
\hline $\mathrm{LOD}(\mu \mathrm{g} / \mathrm{mL})$ & 0.211 & 0.361 \\
\hline $\mathrm{LOQ}(\mu \mathrm{g} / \mathrm{mL})$ & 0.641 & 1.095 \\
\hline
\end{tabular}

Table 1: The determination of the RIV and CLP analytical performance using the proposed first derivative spectrophotometric method 3 .

\begin{tabular}{|c|c|c|}
\hline \multirow{2}{*}{ Parameter } & \multicolumn{2}{|c|}{ Results } \\
\cline { 2 - 3 } & RIV & CLP \\
\hline Linearity range $(\boldsymbol{\mu g} / \mathbf{m L})$ & $2.0-20.0$ & $5.0-60.0$ \\
\hline$(\mathrm{a})$ & 1.02 & 0.59 \\
\hline$(\mathrm{b})$ & 1.94 & 0.082 \\
\hline$(\mathrm{r})$ & 0.9999 & 0.9999 \\
\hline$(\mathrm{Sy} / \mathrm{x})$ & $9.6 \times 10^{-2}$ & $1.68 \times 10^{-2}$ \\
\hline$(\mathrm{Sa})$ & 0.08 & $1.21 \times 10^{-2}$ \\
\hline$(\mathrm{Sb})$ & $6.6 \times 10^{-3}$ & $3.0 \times 10^{-4}$ \\
\hline$\% \mathrm{RSD}$ & 0.41 & 0.96 \\
\hline$\% \mathrm{Error}$ & 0.18 & 0.36 \\
\hline $\mathrm{LOD}(\mu \mathrm{gg} / \mathrm{mL})$ & 0.137 & 0.485 \\
\hline $\mathrm{LOQ}(\mu \mathrm{g} / \mathrm{mL})$ & 0.417 & 1.471 \\
\hline
\end{tabular}

Table 2: The determination of the RIV and CLP analytical performance using the proposed ratio first derivative spectrophotometric method. 
Citation: Sharaf EDM, Ibrahim F, Shalan SH, Abd El-Aziz H (2018) Spectrophotometric Methods for Simultaneous Determination of Rivaroxaban and Clopidogrel in Their Binary Mixture. Pharm Anal Acta 9: 575. doi: 10.4172/2153-2435.1000575

Page 6 of 9

correlation coefficients (r) were of high values indicating high linearity of the proposed methods and the results obeys Beer's law.

Low scattering of the points around the calibration curves was predicted from the small values of the standard deviation of residuals $\left(\mathrm{S}_{\mathrm{y} / \mathrm{x}}\right)$, of intercept $\left(\mathrm{S}_{\mathrm{z}}\right)$, and of slope $\left(\mathrm{S}_{\mathrm{b}}\right)$. Owing to small values of percentage relative standard deviation (RSD\%) and percentage relative errors (\%Er), the proposed method illustrates high accuracy and high precision.

\section{Limit of detection (LOD) and limit of quantitation (LOQ)}

Quantitation limit (LOQ) and detection limit (LOD) were determined according to ICH recommendations [26] using the following equation.

$$
\mathrm{LOQ}=10 \mathrm{~S}_{\mathrm{a}} / \mathrm{b} \mathrm{LOD}=3.3 \mathrm{~S}_{\mathrm{a}} / \mathrm{b}
$$

Where: $\mathrm{S}_{\mathrm{a}}$ is standard deviation of the intercept of the calibration curve and, $b$ is the slope of the calibration curve.

Table 1 shows that: 0.64 and $1.09 \mu \mathrm{g} / \mathrm{mL}$ were LOQ values while 0.21 and $0.36 \mu \mathrm{g} / \mathrm{mL}$ were LOD values for RIV and CLP, respectively for first derivative spectrophotometric method. Table 2 illustrates that: 0.42 and $1.47 \mu \mathrm{g} / \mathrm{mL}$ were LOQ values while 0.14 and $0.48 \mu \mathrm{g} / \mathrm{mL}$ were LOD values for RIV and CLP, respectively for ratio first derivative spectrophotometric method. Table 3 illustrates that: 0.826 and $1.471 \mu \mathrm{g} /$ $\mathrm{mL}$ were LOQ values while 0.272 and $0.485 \mu \mathrm{g} / \mathrm{mL}$ were $\mathrm{LOD}$ values for RIV and CLP, respectively for absorbance ratio spectrophotometric method.

\section{Method accuracy}

The analysis of the obtained results of the proposed methods for the RIV and CLP were compared with those produced using the reference method [13] for proving the accuracy of our proposed method. The obtained results were analyzed statistically using Student's t-test and variance ratio F-test [25] which illustrated no significant difference between both methods performance regarding accuracy and precision, respectively. Student's t-test and variance ratio F-test are presented in Table 4 .

-The precision for proposed methods was determined by (intraday) and (inter-day) assay for both drugs.

\begin{tabular}{|c|c|c|c|c|}
\hline \multirow{3}{*}{$\begin{array}{c}\text { Parameter } \\
\text { Wavelength }(\mathrm{nm})\end{array}$} & \multicolumn{4}{|c|}{ Results } \\
\hline & \multicolumn{2}{|c|}{ RIV } & \multicolumn{2}{|c|}{ CLP } \\
\hline & 233.7 & 248.5 & 233.7 & 248.5 \\
\hline Linearity range $(\mu \mathrm{g} / \mathrm{mL})$ & $2.0-20.0$ & & $5.0-60.0$ & \\
\hline Regression equation & $\begin{array}{l}Y=0.0138 \\
+0.0337 X\end{array}$ & $\begin{array}{l}Y=0.0466 \\
+0.0519 X\end{array}$ & $\begin{array}{c}Y=0.0435+ \\
0.0149 X\end{array}$ & $\begin{array}{c}Y=0.0061+ \\
0.0063 X\end{array}$ \\
\hline Correlation coefficient $(r)$ & 0.9999 & 0.9999 & 0.9999 & 0.9999 \\
\hline S.D. of residuals (Sy/x) & $3.3 \times 10^{-3}$ & & $3.0 \times 10^{-3}$ & \\
\hline S.D. of intercept (Sa) & $2.8 \times 10^{-3}$ & & $2.2 \times 10^{-3}$ & \\
\hline S.D. of slope (Sb) & $2.0 \times 10^{-4}$ & & $1.0 \times 10^{-4}$ & \\
\hline $\begin{array}{c}\text { Percentage relative } \\
\text { standard deviation, \% } \\
\text { RSD }\end{array}$ & 1.02 & 0.74 & 0.79 & 0.67 \\
\hline $\begin{array}{c}\text { Percentage relative error, } \\
\text { \% Error }\end{array}$ & 0.45 & 0.33 & 0.29 & 0.25 \\
\hline Mean & 99.78 & 99.85 & 99.95 & 99.39 \\
\hline $\begin{array}{l}\text { Detection limit, LOD }(\mu \mathrm{g} / \\
\mathrm{mL})\end{array}$ & 0.272 & & 0.485 & \\
\hline $\begin{array}{l}\text { Quantitation limit, LOQ } \\
\qquad(\mu \mathrm{g} / \mathrm{mL})\end{array}$ & 0.826 & & 1.471 & \\
\hline
\end{tabular}

Table 3: The determination of the RIV and CLP analytical performance by the proposed absorbance ratio spectrophotometric method.
Intra-day precision: The three proposed methods were subjected to intra-day precision through replicate analysis of three concentrations of both tested drugs on three different times within the same day. The obtained results showed small values of \% Error and \% RSD indicate high accuracy and precision of the proposed methods, respectively. The outcomes are cited in Tables 5-7.

Inter-day precision: Inter-day precision was carried out through replicate analysis of three concentrations of the studied drugs on three successive days. The results are stated in Tables 5-7.

\begin{tabular}{|c|c|c|c|c|c|}
\hline \multirow{4}{*}{ Proposed method } & \multirow{4}{*}{ Analyte } & \multicolumn{3}{|c|}{ Results } & \multirow{2}{*}{ 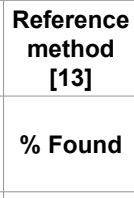 } \\
\hline & & $\begin{array}{c}\text { Amount } \\
\text { taken } \\
(\mu \mathrm{g} / \mathrm{mL})\end{array}$ & $\begin{array}{l}\text { Amount } \\
\text { found } \\
(\mu \mathrm{g} / \mathrm{mL})\end{array}$ & $\%$ Found & \\
\hline & & 2.0 & 1.976 & 98.84 & 98.77 \\
\hline & & 5.0 & 5.000 & 100.00 & 100.44 \\
\hline \multirow{16}{*}{$\begin{array}{c}\text { First derivative } \\
\text { spectrophotometry }\end{array}$} & RIV & 10.0 & 10.058 & 100.58 & 99.90 \\
\hline & & 15.0 & 14.883 & 99.22 & \\
\hline & & 20.0 & 20.000 & 100.00 & \\
\hline & $x \pm S D$ & & & $\begin{array}{c}99.73 \pm \\
0.69\end{array}$ & $\begin{array}{l}99.70 \pm \\
0.85\end{array}$ \\
\hline & t-test & & & $0.05(2.45)$ & \\
\hline & F-test & & & $1.51(6.94)$ & \\
\hline & & 5.0 & 4.9259 & 98.52 & 98.48 \\
\hline & & 10.0 & 9.9877 & 99.88 & 100.55 \\
\hline & CLP & 20.0 & 19.9877 & 99.94 & 99.88 \\
\hline & & 30.0 & 30.2346 & 100.78 & \\
\hline & & 40.0 & 40.2346 & 100.59 & \\
\hline & & 50.0 & 49.987 & 99.98 & \\
\hline & & 60.0 & 59.987 & 99.98 & \\
\hline & $x \pm S D$ & & & $\begin{array}{l}99.95 \pm \\
0.73\end{array}$ & $\begin{array}{l}99.64 \pm \\
1.06\end{array}$ \\
\hline & t-test & & & $0.56(2.31)$ & \\
\hline & F-test & & & $2.12(5.14)$ & \\
\hline \multirow{19}{*}{$\begin{array}{c}\text { Ratio first } \\
\text { derivative } \\
\text { spectrophotometry }\end{array}$} & & $\begin{array}{l}\text { Amount } \\
\text { taken } \\
(\mu \mathrm{g} / \mathrm{mL})\end{array}$ & $\begin{array}{c}\text { Amount } \\
\text { found }(\mu g / \\
m L)\end{array}$ & $\%$ Found & $\%$ Found \\
\hline & & 2.0 & 1.989 & 99.47 & 98.77 \\
\hline & & 5.0 & 4.978 & 99.57 & 100.44 \\
\hline & RIV & 10.0 & 10.020 & 100.21 & 99.9 \\
\hline & & 15.0 & 15.062 & 100.42 & \\
\hline & & 20.0 & 19.950 & 99.75 & \\
\hline & $x \pm S D$ & & & $\begin{array}{c}99.88 \pm \\
0.41\end{array}$ & $\begin{array}{c}99.70 \pm \\
0.85\end{array}$ \\
\hline & t-test & & & $0.41(2.45)$ & \\
\hline & F-test & & & $4.26(6.94)$ & \\
\hline & & 5.0 & 4.942 & 98.86 & 98.48 \\
\hline & & 10.0 & 9.814 & 98.15 & 100.55 \\
\hline & CLP & 20.0 & 20.070 & 100.35 & 99.88 \\
\hline & & 30.0 & 30.180 & 100.60 & \\
\hline & & 40.0 & 40.289 & 100.72 & \\
\hline & & 50.0 & 50.034 & 100.07 & \\
\hline & & 60.0 & 59.778 & 99.63 & \\
\hline & $x \pm S D$ & & & $\begin{array}{l}99.77 \pm \\
0.96\end{array}$ & $\begin{array}{l}99.64 \pm \\
1.06\end{array}$ \\
\hline & t-test & & & $0.19(2.31)$ & \\
\hline & F-test & & & $1.22(5.14)$ & \\
\hline
\end{tabular}


Citation: Sharaf EDM, Ibrahim F, Shalan SH, Abd El-Aziz H (2018) Spectrophotometric Methods for Simultaneous Determination of Rivaroxaban and Clopidogrel in Their Binary Mixture. Pharm Anal Acta 9: 575. doi: 10.4172/2153-2435.1000575

Page 7 of 9

\begin{tabular}{|c|c|c|c|c|c|}
\hline \multirow{19}{*}{$\begin{array}{l}\text { Absorbance ratio } \\
\text { spectrophotometry }\end{array}$} & & $\begin{array}{c}\text { Amount } \\
\text { taken } \\
(\mu \mathrm{g} / \mathrm{mL})\end{array}$ & $\begin{array}{c}\text { Amount } \\
\text { found }(\mu \mathrm{g} / \\
\mathrm{mL})\end{array}$ & $\%$ Found & $\%$ Found \\
\hline & & 2.0 & 1.964 & 98.22 & 98.77 \\
\hline & & 5.0 & 4.991 & 99.82 & 100.44 \\
\hline & RIV & 10.0 & 10.035 & 100.36 & 99.90 \\
\hline & & 15.0 & 15.139 & 100.93 & \\
\hline & & 20.0 & 19.916 & 99.58 & \\
\hline & $x \pm S D$ & & & $\begin{array}{c}99.78 \pm \\
1.02\end{array}$ & $\begin{array}{c}99.70 \pm \\
0.85\end{array}$ \\
\hline & t-test & & & $0.11(2.45)$ & \\
\hline & F-test & & & $1.42(19.24)$ & \\
\hline & & 5.0 & 4.9329 & 98.66 & 98.48 \\
\hline & & 10.0 & 9.9664 & 99.66 & 100.55 \\
\hline & CLP & 20.0 & 19.9664 & 99.83 & 99.88 \\
\hline & & 30.0 & 30.3691 & 101.23 & \\
\hline & & 40.0 & 40.1678 & 100.42 & \\
\hline & & 50.0 & 49.832 & 99.66 & \\
\hline & & 60.0 & 60.100 & 100.17 & \\
\hline & $x \pm S D$ & & & $\begin{array}{c}99.95 \pm \\
0.79\end{array}$ & $\begin{array}{c}99.64 \pm \\
1.06\end{array}$ \\
\hline & t-test & & & $0.52(2.31)$ & \\
\hline & F-test & & & $1.78(5.14)$ & \\
\hline
\end{tabular}

Table 4: Assay results for RIV and CLP determination in their pure form by the three proposed spectrophotometric and reference methods.

\begin{tabular}{|c|c|c|c|}
\hline $\begin{array}{c}\text { Concentration added } \\
(\mu \mathrm{g} / \mathrm{ml})\end{array}$ & $\%$ Found \pm SD & \% RSD & $\%$ Error \\
\hline \multicolumn{4}{|l|}{ RIV } \\
\hline \multicolumn{4}{|l|}{ Intra-day } \\
\hline 2 & $99.65 \pm 0.95$ & 0.95 & 0.55 \\
\hline 5 & $100.34 \pm 0.72$ & 0.72 & 0.41 \\
\hline 10 & $99.35 \pm 0.91$ & 0.91 & 0.53 \\
\hline \multicolumn{4}{|l|}{ Inter-day } \\
\hline 2 & $99.22 \pm 1.00$ & 1 & 0.58 \\
\hline 5 & $100.08 \pm 0.68$ & 0.67 & 0.39 \\
\hline 10 & $100.23 \pm 0.88$ & 0.88 & 0.51 \\
\hline \multicolumn{4}{|l|}{ CLP } \\
\hline \multicolumn{4}{|l|}{ Intra-day } \\
\hline 10 & $100.13 \pm 0.86$ & 0.86 & 0.5 \\
\hline 25 & $100.18 \pm 0.94$ & 0.94 & 0.54 \\
\hline 50 & $99.73 \pm 0.61$ & 0.61 & 0.35 \\
\hline \multicolumn{4}{|l|}{ Inter-day } \\
\hline 10 & $99.33 \pm 1.07$ & 1.08 & 0.62 \\
\hline 25 & $99.71 \pm 0.83$ & 0.83 & 0.48 \\
\hline 50 & $100.44 \pm 0.68$ & 0.68 & 0.39 \\
\hline
\end{tabular}

Table 5: Precision results for the determination of RIV and CLP by the proposed first derivative spectrophotometric method.

The small values of \% Error and \% RSD indicate high accuracy and precision of the proposed method, respectively.

\section{Specificity}

Common tablet excipients may interfere with the assay of the drugs which affect the specificity of the method. The excipients did not interfere with the results of our proposed methods indicating high specificity of the method. The specificity of the proposed method was investigated by viewing any interference of common tablets excipients such as talc powder, lactose, maize starch, magnesium stearate, calcium hydrogen phosphate and microcrystalline cellulose.

\begin{tabular}{|c|c|c|c|}
\hline $\begin{array}{c}\text { Concentration added } \\
(\mu \mathrm{g} / \mathrm{ml})\end{array}$ & $\%$ Found \pm SD & $\%$ RSD & $\%$ Error \\
\hline \multicolumn{4}{|l|}{ RIV } \\
\hline \multicolumn{4}{|l|}{ Intra-day } \\
\hline 2 & $98.99 \pm 0.72$ & 0.72 & 0.61 \\
\hline 5 & $100.00 \pm 0.65$ & 0.65 & 0.54 \\
\hline 10 & $99.14 \pm 0.93$ & 0.93 & 0.59 \\
\hline \multicolumn{4}{|l|}{ Inter-day } \\
\hline 2 & $100.08 \pm 0.53$ & 0.53 & 0.51 \\
\hline 5 & $99.26 \pm 0.68$ & 0.68 & 0.49 \\
\hline 10 & $100.20 \pm 0.58$ & 0.58 & 0.52 \\
\hline \multicolumn{4}{|l|}{ CLP } \\
\hline \multicolumn{4}{|l|}{ Intra-day } \\
\hline 10 & $100.24 \pm 0.76$ & 0.76 & 0.5 \\
\hline 25 & $101.00 \pm 0.84$ & 0.84 & 0.56 \\
\hline 50 & $99.80 \pm 0.67$ & 0.67 & 0.45 \\
\hline \multicolumn{4}{|l|}{ Inter-day } \\
\hline 10 & $99.18 \pm 0.84$ & 0.84 & 0.61 \\
\hline 25 & $100.25 \pm 0.73$ & 0.73 & 0.47 \\
\hline 50 & $100.04 \pm 0.66$ & 0.66 & 0.38 \\
\hline
\end{tabular}

Table 6: Precision data for RIV and CLP assay by the proposed ratio first derivative spectrophotometric method.

\begin{tabular}{|c|c|c|c|}
\hline $\begin{array}{c}\text { Concentration added } \\
(\mu \mathrm{g} / \mathrm{ml})\end{array}$ & $\%$ Found \pm SD & $\%$ RSD & $\%$ Error \\
\hline \multicolumn{4}{|l|}{ RIV } \\
\hline \multicolumn{4}{|l|}{ Intra-day } \\
\hline 2 & $99.60 \pm 0.49$ & 0.49 & 0.64 \\
\hline 5 & $100.18 \pm 0.71$ & 0.71 & 0.44 \\
\hline 10 & $99.15 \pm 0.88$ & 0.88 & 0.56 \\
\hline \multicolumn{4}{|l|}{ Inter-day } \\
\hline 2 & $100.02 \pm 0.62$ & 0.62 & 0.53 \\
\hline 5 & $99.55 \pm 0.74$ & 0.74 & 0.6 \\
\hline 10 & $100.43 \pm 0.56$ & 0.56 & 0.55 \\
\hline \multicolumn{4}{|l|}{ CLP } \\
\hline \multicolumn{4}{|l|}{ Intra-day } \\
\hline 10 & $100.00 \pm 0.77$ & 0.77 & 0.52 \\
\hline 25 & $99.75 \pm 0.85$ & 0.85 & 0.57 \\
\hline 50 & $99.86 \pm 0.66$ & 0.66 & 0.47 \\
\hline \multicolumn{4}{|l|}{ Inter-day } \\
\hline 10 & $99.44 \pm 0.90$ & 0.9 & 0.6 \\
\hline 25 & $100.05 \pm 0.74$ & 0.74 & 0.39 \\
\hline 50 & $100.54 \pm 0.55$ & 0.55 & 0.51 \\
\hline
\end{tabular}

Table 7: Precision results for RIV and CLP determination by the proposed absorbance ratio spectrophotometric method.

\begin{tabular}{|c|c|c|c|c|c|c|}
\hline \multirow{3}{*}{$\begin{array}{l}\text { RIV/CLP } \\
\text { ratio }\end{array}$} & \multicolumn{6}{|c|}{ Proposed method } \\
\hline & \multicolumn{2}{|c|}{$\begin{array}{l}\text { Amount taken } \\
(\mu \mathrm{g} / \mathrm{ml})\end{array}$} & \multicolumn{2}{|c|}{$\begin{array}{l}\text { Amount found ( } \mu \mathrm{g} / \\
\mathrm{ml})\end{array}$} & \multicolumn{2}{|c|}{$\%$ Found } \\
\hline & RIV & CLP & RIV & CLP & RIV & CLP \\
\hline \multirow[t]{3}{*}{$1: 5$} & 2.0 & 10.0 & 1.9745 & 10.00 & 98.73 & 100.00 \\
\hline & 5.0 & 25.0 & 5.0357 & 24.82 & 100.71 & 99.29 \\
\hline & 10.0 & 50.0 & 9.9847 & 49.82 & 99.85 & 99.64 \\
\hline Mean & & & & & 99.76 & 99.64 \\
\hline $\pm S D$ & & & & & \pm 0.99 & \pm 0.36 \\
\hline \% RSD & & & & & 0.99 & 0.36 \\
\hline$\%$ Error & & & & & 0.57 & 0.21 \\
\hline
\end{tabular}

Table 8: Results for RIV and CLP determination in synthetic mixtures in ratios of $1: 5(\mathrm{w} / \mathrm{w})$ by the proposed first derivative method. 
Citation: Sharaf EDM, Ibrahim F, Shalan SH, Abd El-Aziz H (2018) Spectrophotometric Methods for Simultaneous Determination of Rivaroxaban and Clopidogrel in Their Binary Mixture. Pharm Anal Acta 9: 575. doi: 10.4172/2153-2435.1000575

Page 8 of 9

\begin{tabular}{|c|c|c|c|c|c|c|}
\hline \multirow{3}{*}{$\begin{array}{l}\text { RIV/CLP } \\
\text { ratio }\end{array}$} & \multicolumn{6}{|c|}{ Proposed method } \\
\hline & \multicolumn{2}{|c|}{$\begin{array}{c}\text { Amount taken } \\
(\mu \mathrm{g} / \mathrm{ml})\end{array}$} & \multicolumn{2}{|c|}{ Amount found $(\mu \mathrm{g} / \mathrm{ml})$} & \multicolumn{2}{|c|}{$\%$ Found } \\
\hline & RIV & CLP & RIV & CLP & RIV & CLP \\
\hline \multirow{3}{*}{ 1:5 } & 2.0 & 10.0 & 1.9841 & 9.8799 & 99.21 & 98.80 \\
\hline & 5.0 & 25.0 & 5.0254 & 25.192 & 100.51 & 100.77 \\
\hline & 10.0 & 50.0 & 9.9904 & 49.927 & 99.9 & 99.85 \\
\hline & & & & & 99.87 & 99.81 \\
\hline $\pm S D$ & & & & & \pm 0.65 & \pm 0.99 \\
\hline$\%$ RSD & & & & & 0.65 & 0.99 \\
\hline$\%$ Error & & & & & 0.37 & 0.57 \\
\hline
\end{tabular}

Table 9: Results for RIV and CLP determination in synthetic mixtures in ratios of 1:5 $(\mathrm{w} / \mathrm{w})$ by the proposed ratio first derivative method.

\begin{tabular}{|c|c|c|c|c|c|c|}
\hline \multirow{3}{*}{$\begin{array}{l}\text { RIV/CLP } \\
\text { ratio }\end{array}$} & \multicolumn{6}{|c|}{ Proposed method } \\
\hline & \multicolumn{2}{|c|}{$\begin{array}{l}\text { Amount taken }(\mu \mathrm{g} / \\
\mathrm{ml})\end{array}$} & \multicolumn{2}{|c|}{$\begin{array}{l}\text { Amount found ( } \mu \mathrm{g} / \\
\mathrm{ml})\end{array}$} & \multicolumn{2}{|c|}{$\%$ Found } \\
\hline & RIV & CLP & RIV & CLP & RIV & CLP \\
\hline \multirow{4}{*}{ 1:5 } & 2.0 & 10.0 & 1.967 & 10.100 & 98.35 & 101.00 \\
\hline & 5.0 & 25.0 & 5.010 & 24.89 & 100.2 & 99.56 \\
\hline & 10.0 & 50.0 & 10.030 & 49.840 & 100.30 & 99.68 \\
\hline & & & & & 99.62 & 100.08 \\
\hline $\pm S D$ & & & & & \pm 1.09 & \pm 0.79 \\
\hline \% RSD & & & & & 1.09 & 0.79 \\
\hline$\%$ Error & & & & & 0.63 & 0.46 \\
\hline
\end{tabular}

Table 10: Results for RIV and CLP determination in synthetic mixtures in ratios of $1: 5(\mathrm{w} / \mathrm{w})$ by the proposed absorbance ratio method.

\section{Robustness}

The robustness of the method was assessed by evaluating the influence of small variations in the experimental variables on the analytical performance of the method. The small variations in any of the variables did not significantly affect the results; percentage recovery was $99.78 \pm 1.02$ and $99.95 \pm 0.79$ for RIV and CLP respectively. This provided an indication of the reliability of the proposed methods during routine work.

\section{Ruggedness}

For expressing the stability of the method against extraneous influencing factors such as analyst, laboratory, instrument. The proposed method provided stable results in different laboratories which indicate reliability of the proposed method.

\section{Application of the Proposed Methods to the Determination of RIV/CLP in Laboratory-Prepared Mixtures}

Simultaneous evaluation of RIV and CLP in laboratory prepared binary mixtures in their pharmaceutical ratio; 1:5 was performed as an application of the proposed methods. In the laboratory prepared mixtures, the concentrations taken of both drugs were presented in the linearity range. The values of \%RSD and \%Er were calculated and the results indicate high accuracy of the proposed method as shown in Tables 8-10.

\begin{tabular}{|c|c|c|c|c|c|c|c|c|}
\hline \multirow{4}{*}{$\begin{array}{l}\text { Laboratory prepared co- } \\
\text { formulated tablets (RIV } \\
15 \mathrm{mg}+\text { CLP } 75 \mathrm{mg} \text { ) }\end{array}$} & \multicolumn{6}{|c|}{ First derivative spectrophotometric method } & \multirow{2}{*}{\multicolumn{2}{|c|}{$\begin{array}{c}\text { Reference method [13] } \\
\text { \% Found }\end{array}$}} \\
\hline & \multicolumn{2}{|c|}{ Amount taken $(\mu \mathrm{g} / \mathrm{ml})$} & \multicolumn{2}{|c|}{ Amount found $(\mu \mathrm{g} / \mathrm{ml})$} & \multicolumn{2}{|c|}{$\%$ Found } & & \\
\hline & RIV & CLP & RIV & CLP & RIV & CLP & RIV & CLP \\
\hline & 2.0 & 10.0 & 2.000 & 9.9394 & 100.00 & 99.39 & 99.37 & 100.47 \\
\hline & 5.0 & 25.0 & 5.026 & 25.0909 & 100.53 & 100.36 & 100.47 & 99.65 \\
\hline & 10.0 & 50.0 & 10.026 & 49.9394 & 100.26 & 99.88 & 99.92 & 100.06 \\
\hline Mean & & & & & 100.26 & 99.88 & 99.92 & 100.06 \\
\hline \pm SD & & & & & \pm 0.27 & \pm 0.49 & \pm 0.55 & \pm 0.41 \\
\hline$\%$ RSD & & & & & 0.27 & 0.49 & 0.55 & 0.41 \\
\hline$\%$ Error & & & & & 0.15 & 0.28 & 0.32 & 0.24 \\
\hline Student $\mathrm{t}$ test & & & & & 0.97 & 0.5 & & \\
\hline $\mathbf{F}$ & & & & & 4.31 & 1.39 & & \\
\hline
\end{tabular}

Table 11: Assay results for RIV and CLP determination in their laboratory prepared tablet by the proposed first derivative spectrophotometric and reference method.

\begin{tabular}{|c|c|c|c|c|c|c|c|c|}
\hline \multirow{6}{*}{$\begin{array}{l}\text { Laboratory prepared co- } \\
\text { formulated tablets (RIV } 15 \\
\text { mg +CLP } 75 \mathrm{mg})\end{array}$} & \multicolumn{6}{|c|}{ Ratio first derivative spectrophotometric method } & \multirow{2}{*}{\multicolumn{2}{|c|}{$\begin{array}{c}\text { Reference } \\
\text { \% Found }\end{array}$}} \\
\hline & \multicolumn{2}{|c|}{ Amount taken $(\mu \mathrm{g} / \mathrm{ml})$} & \multicolumn{2}{|c|}{ Amount found $(\mu \mathrm{g} / \mathrm{ml})$} & \multicolumn{2}{|c|}{$\%$ Found } & & \\
\hline & RIV & CLP & RIV & CLP & RIV & CLP & RIV & CLP \\
\hline & 2.0 & 10.0 & 1.983 & 9.9211 & 99.19 & 99.21 & 99.37 & 100.47 \\
\hline & 5.0 & 25.0 & 5.026 & 25.1384 & 100.52 & 100.55 & 100.47 & 99.65 \\
\hline & 10.0 & 50.0 & 9.99 & 49.9668 & 99.9 & 99.93 & 99.92 & 100.06 \\
\hline Mean & & & & & 99.87 & 99.9 & 99.92 & 100.06 \\
\hline $\pm S D$ & & & & & \pm 0.67 & \pm 0.67 & \pm 0.55 & \pm 0.41 \\
\hline$\%$ RSD & & & & & 0.67 & 0.67 & 0.55 & 0.41 \\
\hline$\%$ Error & & & & & 0.38 & 0.38 & 0.32 & 0.24 \\
\hline Student $\mathrm{t}$ test & & & & & 0.1 & 0.36 & & \\
\hline $\mathbf{F}$ & & & & & 1.46 & 2.67 & & \\
\hline
\end{tabular}

Table 12: Results of RIV and CLP assay in their laboratory prepared tablet by the proposed ratio first derivative spectrophotometric and reference method. 
Citation: Sharaf EDM, Ibrahim F, Shalan SH, Abd El-Aziz H (2018) Spectrophotometric Methods for Simultaneous Determination of Rivaroxaban and Clopidogrel in Their Binary Mixture. Pharm Anal Acta 9: 575. doi: 10.4172/2153-2435.1000575

Page 9 of 9

\begin{tabular}{|c|c|c|c|c|c|c|c|c|}
\hline \multirow{6}{*}{$\begin{array}{c}\text { Laboratory prepared } \\
\text { co-formulated tablets } \\
\text { (RIV } 15 \mathrm{mg}+\text { CLP } 75 \\
\text { mg ) }\end{array}$} & \multicolumn{6}{|c|}{ Ratio first derivative spectrophotometric method } & \multirow{2}{*}{\multicolumn{2}{|c|}{$\begin{array}{c}\text { Reference } \\
\% \text { Found }\end{array}$}} \\
\hline & \multicolumn{2}{|c|}{ Amount taken $(\mu \mathrm{g} / \mathrm{ml})$} & \multicolumn{2}{|c|}{ Amount found $(\mu \mathrm{g} / \mathrm{ml})$} & \multicolumn{2}{|c|}{$\%$ Found } & & \\
\hline & RIV & CLP & RIV & CLP & RIV & CLP & RIV & CLP \\
\hline & 2.0 & 10.0 & 2.003 & 9.892 & 100.15 & 98.92 & 99.37 & 100.47 \\
\hline & 5.0 & 25.0 & 5.061 & 25.040 & 101.22 & 100.16 & 100.47 & 99.65 \\
\hline & 10.0 & 50.0 & 9.950 & 50.00 & 99.50 & 100.00 & 99.92 & 100.06 \\
\hline Mean & & & & & 100.29 & 99.69 & 99.92 & 100.06 \\
\hline \pm SD & & & & & \pm 0.87 & \pm 0.67 & \pm 0.55 & \pm 0.41 \\
\hline$\%$ RSD & & & & & 0.87 & 0.67 & 0.55 & 0.41 \\
\hline$\%$ Error & & & & & 0.50 & 0.39 & 0.32 & 0.24 \\
\hline Student $t$ test & & & & & 0.62 & 0.80 & & \\
\hline $\mathbf{F}$ & & & & & 2.49 & 2.71 & & \\
\hline
\end{tabular}

Table 13: Assay results for RIV and CLP determination in their laboratory prepared tablet by the proposed absorbance ratio spectrophotometric and reference method.

\section{Application of the Proposed Methods to the Determination of the Studied Drugs in Laboratory Prepared Co-formulated Tablets}

Our proposed methods were applied for the estimation of both tested drugs in their prepared tablets. Tables 11-13 showed that the results obtained are in good agreement with the results of the comparison one [13]. The obtained data were statistically analyzed using Student's t-test and variance ratio F-test [24] showing no significant difference between the performance of the two methods, so our method is of high accuracy and precision.

\section{Conclusion}

RIV and CLP binary mixtures were analyzed using an accurate, sensitive, and rapid three spectrophotometric methods. Also, the studied drugs could be determined in prepared tablets using the proposed spectrophotometric procedures. These proposed methods can be applied in quality control laboratories, science it showed good validation criteria.

\section{References}

1. Moffat AC, Osselton MD, Widdop B (2004) Clarke's analysis of drugs \& poisons. (3rd edn.) Pharmaceutical Press, UK.

2. Sweetman SC (2009) martindale the complete drug reference. (36 ${ }^{\text {th }}$ edn.) The Pharmaceutical Press, UK

3. Sekaran CB, Bind VH, Damayanthi MR, Sireesha A (2013) Development and validation of UV spectrophotometric method for the determination of rivaroxaban. Der Pharma Chemica 5: 1-5.

4. Lories IB, Mostafa AA, Girges MA (2013) High performance liquid chromatography, TLC densitometry, First-derivative and First-derivative ratio spectrophotometry for determination of rivaroxaban and its alkaline degradates in bulk powder and its tablets. J Chromatogr Sep Tech 4: 1-6.

5. Vaghela D, Patel P (2014) High performance thin layer chromatographic method with densitometry analysis for determination of rivaroxaban from its tablet dosage form. Intl J Pharm Pharma Sci 6: 383-386.

6. Debnath S, Hati S, Bhattacharya P, Saha A (2014) Exploring validated HPTLC method of Rivaroxaban in tablet dosage form. J Indian Chem Soc 91: 299-304.

7. Walter ME, Perobelli RF, Da Silva FS, Cardoso Junior CD, da Silva IS, et al (2015) Development and validation of a stability-indicating RP-HPLC method for the determination of rivaroxaban in pharmaceutical formulations. LAT AM J PHARM 34: 1503-1510.

8. Ping C, Ancheng J, Aihua Z, Yimei D (2015) Chiral separation and determination of rivaroxaban and its isomer by HPLC. Zhongguo Yiyao Gongye Zazhi 46 : 1220-1222.

9. Hetal J, Batuk D, Madhavi P, Yashwantsinha J (2015) Stress study and estimation of a potent anticoagulant drug rivaroxaban by a validated HPLC method: Technology transfer to UPLC. J Chem Pharm Res 7: 65-74.
10. Lu C, Jun C (2014) Determination of rivaroxaban in human plasma by HPLCMS/MS. Zhongguo Yiyuan Yaoxue Zazhi 34: 1653-1656.

11. Seshamamba BSV, Venkata PV (2014) Application of stability indicating HPLC method with UV detector to the analysis of rivaroxaban in bulk and tablet dosage form. Chem Sci Trans 3: 1546-1554.

12. Çelebier M, Reçber T, Koçak E, Altinöz S (2013) RP-HPLC method development and validation for estimation of rivaroxaban in pharmaceutical dosage forms. BRAZ J PHARM SCI 49: 359-366.

13. Prajapati AM, Patel HA (2015) Simultaneous RP-HPLC method development and validation of clopidogrel and rivaroxaban in synthetic mixture. Int J Pharm 5: 610-613.

14. The United States Pharmacopeia 34th and The National Formulary 29th, Rockville, MD, USA.

15. The British Pharmacopoeia (2015) Her Magesty's Stationary Office, UK, pp: 599-601.

16. Rajendra VB, Deshmukh OJ, Rawat PK, Gulecha BS, Khushwaha Sh, et al. (2012) Spectrophotometric method for the estimation of Clopidogrel bisulphate residue in swab samples. World J Pharmac Res 3: 850-858.

17. Cholke PB, Ahmed R, Chemate SZ, Jadhav KR (2012) Development and Validation of Spectrophotometric Method for Clopidogrel bisulfate in pure and in film coated tablet dosage form. Arch Appl Sci Res 4: 59-64.

18. Gurav S, Venkatamahesh R (2012) Development and Validation of Derivative UV-Spectropotometric Methods for Quantitative Estimation of Clopidogrel in Bulk and Pharmaceutical Dosage Form. Int J Chem Tech Res 4: 497-501.

19. Kale AB, Mohanty P, Choudhari VP, Sutar AS, Jagdale SC, et al. (2011) Spectrophotometric Simultaneous Determination of Clopidogrel and Aspirin in Combined Tablet Dosage Form by Ratio Derivative and Area Under Curve Method. Res J Pharm Technol 4: 105-108.

20. Swathi K, Chaitanya M, Swathi K (2015) Method development and its validation for simultaneous estimation of ramipril \& clopidogrel by RP-HPLC in combination tablet dosage form. Int J Pharma Res Health Sci 3: 737-741.

21. Elzanfaly ES, Zaazaa HE, Soudi AT, Salem MY (2015) Validated chiral chromatographic methods for clopidogrel bisulphate and its related substances in bulk drug and pharmaceutical dosage forms. Chem Pap 69: 1541-1547.

22. Chatrabhuji PM, Pandya CV, Patel MC (2014) Development and validation of RP-HPLC-UV method for simultaneous quantitation of clopidogrel bisulphate and aspirin in bulk drug. Anal Chem: Indian J 15: 43-48.

23. Raja B, Lakshmana Rao A (2014) Development and validation of RP-HPLC method for simultaneous determination of Rosuvastatin and Clopidogrel in pharmaceutical formulations. Pharmanest 5: 2123-2129.

24. Beckett AH, Stenlake JB (1988) Practical Pharmaceutical chemistry.

25. Miller JN, Miller JC (2005) Statistics and Chemometrics for Analytical Chemistry ( $5^{\text {th }}$ edn) Pearson Education Limited, UK.

26. http://www.ich.org/LOB/media/MEDIA417.pdf 